\title{
Return Statements
}




\section{Incitements}

Series editors: Peg Birmingham, DePaul University and Dimitris Vardoulakis, University of Western Sydney

An incitement is a thought that leads to a further thought or an action that solicits a response, while also testing the limits of what is acceptable or lawful. The books in this series, by prominent, world class scholars, will highlight the political import of philosophy, showing how concepts can be translated into political praxis, and how praxis is inextricably linked to thinking.

\section{Editorial Advisory Board}

Étienne Balibar, Andrew Benjamin, Jay M. Bernstein, Rosi Braidotti, Wendy Brown, Judith Butler, Adriana Cavarero, Howard Caygill, Joan Copjec, Simon Critchley, Rebecca Comay, Costas Douzinas, Peter Fenves, Christopher Fynsk, Moira Gatens, Gregg Lambert, Leonard Lawlor, Genevieve Lloyd, Catherine Malabou, James Martel, Christoph Menke, Warren Montag, Michael Naas, Antonio Negri, Kelly Oliver, Paul Patton, Anson Rabinbach, Gerhard Richter, Martin Saar, Miguel Vatter, Gianni Vattimo, Santiago Zabala

\section{Available}

Return Statements: The Return of Religion in Contemporary Philosophy

By Gregg Lambert

The Refusal of Politics

By Laurent Dubreuil, translated by Cory Browning

Plastic Sovereignties: Agamben and the Politics of Aesthetics

By Arne De Boever

From Violence to Speaking Out

By Leonard Lawlor

\section{Forthcoming}

Agonistic Mourning: Counter-Memory and Feminist Political Dissidence in Post-Yugoslavia By Athena Athanasiou 


\section{Return Statements}

The Return of Religion in Contemporary Philosophy

\section{Gregg Lambert}


Edinburgh University Press is one of the leading university presses in the UK. We publish academic books and journals in our selected subject areas across the humanities and social sciences, combining cutting-edge scholarship with high editorial and production values to produce academic works of lasting importance. For more information visit our website: www.edinburghuniversitypress.com

(C) Gregg Lambert, 2016

Edinburgh University Press Ltd

The Tun - Holyrood Road, 12(2f) Jackson's Entry, Edinburgh EH8 8PJ

Typeset in Bembo

by R. J. Footring Ltd, Derby, UK, and printed and bound in Great Britain by CPI Group (UK) Ltd, Croydon CR0 4YY

A CIP record for this book is available from the British Library

\author{
ISBN 9781474413909 (hardback) \\ ISBN 9781474413923 (webready PDF) \\ ISBN 9781474413916 (paperback) \\ ISBN 9781474413930 (epub)
}

The right of Gregg Lambert to be identified as the author of this work has been asserted in accordance with the Copyright, Designs and Patents Act 1988, and the Copyright and Related Rights Regulations 2003 (SI No. 2498). 